\title{
EFFECT OF SEED-SOAKING IN POLY ETHYLENE GLYCOL AND HUMIC ACID ON THE PRODUCTIVITY AND QUALITY OF FODDER BEET UNDER SOIL SALINITY CONDITIONS. \\ Zizy M. Abbas ${ }^{1}$; H.O. Sakr ${ }^{2}$; Rama.T. Rashad ${ }^{2}$ and Kh. A. Shaban ${ }^{2}$ 1- Field Crops Research Institute, Agricultural Research Centre, Giza, Egypt. \\ 2- Soils, Water and Environment Research Institute, Agricultural p
}

\begin{abstract}
Two field experiments were conducted at El-Serw Agricultural Experiment and Research Station, during two successive winter seasons $2011 / 2012$ and $2012 / 2013$, to study the effect of soaking seeds in solutions of poly ethylene glycol (PEG) and humic acid (HA) on growth, yield, and nutrients contents of fodder beet (Beta vulgaris $L$. (vorochenger) grown in newly reclaimed saline soils conditions.

Results showed positive effects of soaked seeds compared to the unsoaked seeds. At soaking time $12 \mathrm{~h}$, the increases due to HA treatments were greater than those attributed to PEG. Soil pH was almost unchanged, the EC values were decreased by $35.5 \%$ and $37.99 \%$ while soil available NPK were increased by $28.44 \%$ and $33.65 \%$ for $\mathrm{N}$; by $11.28 \%$ and $96.24 \%$ for $P$ while $K$ was increased by $13.14 \%$ and $18.5 \%$ for both $P E G$ and $H A$ treatments respectively compared with the control. The fresh and dry weights of root were increased by $133.3 \%$ and $136.86 \%$, respectively, for PEG treatments. For HA treatments, the increases in the above mentioned characteristics amounted $155.26 \%$ and $161.63 \%$, respectively. Root length and diameter were enhanced significantly. the increases in roots $\mathrm{N}$ content amounted 21.74 and $29.5 \%, \mathrm{P}$ by 37.88 and $50 \%, \mathrm{~K}$ by 7.82 and $12.35 \%$ and Protein by 21.71 and $26.63 \%$ for PEG and HA, respectively. The leaves chlorophyll content (ChI) was increased by $84.43 \%$ and $156.51 \%$ and emergence by $36.36 \%$ and $42.15 \%$ while the proline decreased by $16.07 \%$ and $25.71 \%$ for $P E G$ and $H A$, respectively.

Keywords: Seed-Soaking; Polymers; Emergence; Chlorophyll; Salinity Stress.

\section{INTRODUCTION}

The semiarid climate and the progressive land Salinization are severe problems affecting the seed germination and plant growth causing yield decrease in many crops. Under nutrient stress conditions, the plant accumulates reactive oxygen species (ROS) and results in oxidative burst inside the plant cells (Yang et al., 2011). Plants can cope with reduced nutrient availability conditions by trigger physiological responses to increase nutrient acquisition that may alter the whole plant morphology and metabolism.
\end{abstract}


One of the advanced methods for accelerating crop plant seed germination is the use of the technology of seed dehydration to increase the ability of seeds to germinate and grow under stress conditions. Seeds are subjected to low potential osmotic solutions of substances such as polyethylene glycol (PEG), $\mathrm{KNO}_{3}, \mathrm{NaCl}$, glycerol, and mannitol. The morphological structure of seed has hardly been related to salt tolerance and seed coat may have an important role in the ion exchange greater than simply as a physical protective barrier. Ethylene was synthesized by poly ethylene glycol (PEG)-treated plants. It was involved in the induction of early senescence processes characterized by synthesis of ROS, per-oxidation of membrane lipids and a decrease in chlorophyll content (Ben Hassine and Lutts, 2010; Mardani et al., 2013). Polyethylene glycol simulates osmotic stress effects, cannot enter seeds and does not cause the side effects produced by salts (Yasari et al., 2013). Higher EN biosynthesis can effectively mitigate salt stress evoked by the accumulation of high levels of $\mathrm{Na}$ in seed tissues. $\mathrm{NaCl}$ inhibited germination of Stylosanthes seeds, Medicago sativa (L.), Astragalus adsurgens (Pall.) and Coronilla varia (L.) through inhibition of EN biosynthesis (Wu et al., 2011; Silva et al., 2014).

Ethylene-responsive element binding factors (ERFs) like CitERF, are a member of the gene family of plant transcription factors suggested to play an important role in improving tolerance to drought and salt stress. CitERF expression had induced continuously during the treatment by 10\% PEG but it could be induced to high level at $1 \mathrm{~h}$ after the treatment at $4{ }^{\circ} \mathrm{C}$ or $250 \mathrm{mM}$ $\mathrm{NaCl}$ and then declined continuously (Yang et al., 2011). Poly ethylene glycol as a water-soluble polymer of low toxicity used to create high osmotic pressure in biochemistry and bio-membrane technologies. It has a positive effect on the hydrolysis of different ligno-cellulose materials due its interaction with lignin. The addition of PEG 4000 at $1 \mathrm{~g}$ (g substrate), enzyme concentration and hydrolysis time could be reduced by approximately two thirds and one third, respectively, without loss in sugars yield (Ivetić et al., 2012).

EN could help plants to retain $\mathrm{K}$ in shoots and roots to improve salt tolerance. In a similar manner, $\mathrm{Ca}, \mathrm{Mg}, \mathrm{Zn}, \mathrm{Fe}, \mathrm{Mn}, \mathrm{Cu}$, Se can be involved. A complete understanding of the EN and nutrients interaction would provide new strategies for improving crop vigor and development under changing environment (lqbal et al., 2013).

The effects of different treatments of PEG on corn grains germination were studied. The maximum germination rate was achieved by priming for 12 hours with 5\% PEG (Yasari et al., 2013). On the other hand, rate of wheat germination was improved when the seed soaked $\mathrm{KNO}_{3} 2 \%$ compared with PEG, KCL and water (Ajirloo et al., 2013). The root length increased at lower concentration of PEG (1\% and 5\%) but decreased at higher PEG concentration. At $1 \%$ PEG concentration chlorophyll content increased compared to control. The results demonstrate a concentration dependent decline in the chlorophyll content with increasing concentration of PEG-6000 while proline content increased significantly. Decrease in the percentage and rate of germination and seedling growth by PEG stress is observed in Senna occidentalis and Zea maize (Jain et al., 2013). Effect of PEG on the amount 
of chlorophyll a, chlorophyll $\mathrm{b}$ and the total leaf of sugar beet have been studied previously (Nagl et al., 2010; Fahim et al., 2014).

Humic substances constituting $65-75 \%$ of organic matter with major functional groups include carboxyl, phenolic hydroxyl, alcoholic hydroxyl and ketone. Humic acid (HA) application increase plant growth parameters under salinity condition depending on the crop species. It is safe, increased the uptake of $\mathrm{P}, \mathrm{K}, \mathrm{Mg}, \mathrm{Na}, \mathrm{Cu}$ and $\mathrm{Zn}$, increased macro-nutrient contents and enhanced micro-nutrient contents of the plant organs by increasing the permeability of root cells membranes (Valdrighi et al., 1996). The seedsoaked in HA have been significantly reduced the damaging action of salinity on plant growth and enhanced the yield production of sugar beet under saline conditions (Eisa et al., 2012).

The present study aims to evaluate the effect of seed-soaking in poly ethylene glycol and humic acid on the productivity and quality of fodder beet under salinity conditions.

\section{MATERIALS AND METHODS}

Two field experiments were conducted at El-Serw Agricultural Experiment and Research Station, during two successive winter seasons $2011 / 2012$ and $2012 / 2013$. The aim is to study the effect of soaking seeds of fodder beet (Beta vulgaris $L$. (vorochenger) in solutions of PEG and HA on growth, yield, and nutrients contents of fodder beet grown in newly reclaimed saline soils conditions. Some physical and chemical properties of a representative soil sample used in the experiment were determined before preparation according to Jackson, (1973) and data are presented in Table 1. Soil particle size distribution was determined by the international Pipette method (Piper, 1950). Soil available $\mathrm{N}$ was extracted using $2 \mathrm{~N} \mathrm{KCl}$ solution and measured according to the modified Kjeldahel method. Available P was extracted by $0.5 \mathrm{~N}$ sodium-bicarbonate and determined colorimetrically (Olsen and Sommers, 1982). Available $\mathrm{K}$ was determined using the FlamePhotometer (Chapman and Pratt, 1961).

Table (1): Some of the physical and chemical properties of the soil before planting.

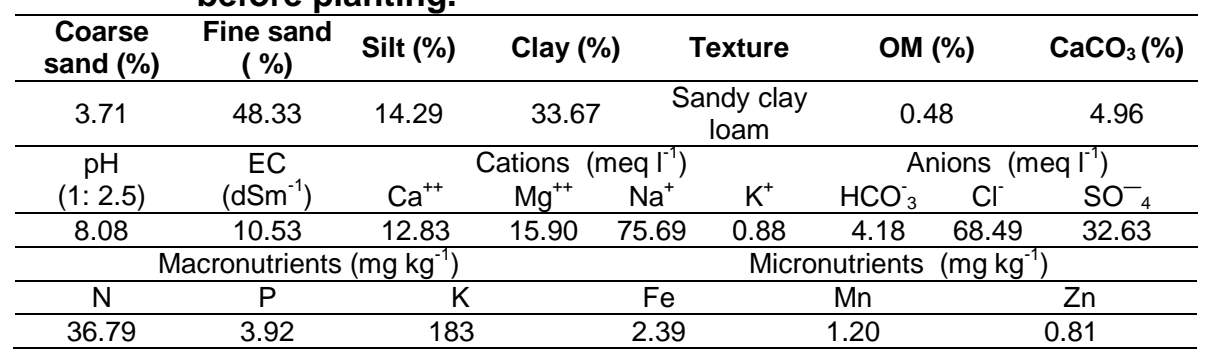


Table (2):Humic analysis.

\begin{tabular}{|c|c|c|c|c|c|c|c|c|}
\hline \multirow{2}{*}{$\mathbf{p H}$} & \multirow{2}{*}{$\begin{array}{c}\mathbf{E C} \\
\left(\mathbf{d S m}^{-1}\right)\end{array}$} & \multirow{2}{*}{$\begin{array}{c}\text { O.M. } \\
(\%)\end{array}$} & \multicolumn{3}{|c|}{$\begin{array}{c}\text { Macronutrients } \\
(\%)\end{array}$} & \multicolumn{3}{|c|}{$\begin{array}{c}\text { Micronutrients } \\
\text { (mg kg) }\end{array}$} \\
\cline { 4 - 9 } & & & $\mathbf{N}$ & $\mathbf{P}$ & $\mathbf{K}$ & $\mathbf{F e}$ & $\mathbf{M n}$ & $\mathbf{Z n}$ \\
\hline 7.85 & 2.14 & 68.00 & 2.18 & 0.29 & 3.48 & 395 & 273 & 218 \\
\hline
\end{tabular}

\section{Planting and fertilization}

The area of each plot was $50 \mathrm{~m}^{2}$ (10 m length $\times 5 \mathrm{~m}$ width), with six ridges $50 \mathrm{~cm}$ apart, $3.5 \mathrm{~m}$ in length. Sowing during the $1^{\text {st }}$ and $2^{\text {nd }}$ seasons was on the $5^{\text {th }}$ of November 2011/2012 and 2012/2013, respectively. Seeds of (Beta vulgaris L. (vorochenger) were soaked in PEG-6000 or HA solution (3g PEG/L dist. $\mathrm{H}_{2} \mathrm{O}-20 \mathrm{~L}$ for $4 \mathrm{~kg}$ seed) for $6,8,12 \mathrm{hr}$ before planting and sown in hills $25 \mathrm{~cm}$ apart (3-4 seeds per hill). Plants were thinned to two plants per hill after 30 days from planting, and then were thinned to one plant per hill after 45 days from planting. Nitrogen fertilization was used in the form of urea $(46 \% \mathrm{~N})$ at a rate of $100 \mathrm{~kg} \mathrm{~N} \mathrm{fed}^{-1}$ and added in three equal doses after 21,45 and 60 days. Potassium fertilizer as potassium sulphate $(48 \%$ $\mathrm{K}_{2} \mathrm{O}$ ) was applied at a rate of $75 \mathrm{~kg} \mathrm{~K}_{2} \mathrm{O}$ fed in two doses after plant thinning and after 60 days from planting. Phosphorous fertilizer as calcium super phosphate was applied at a rate of $200 \mathrm{~kg} \mathrm{fed}^{-1}\left(15.5 \% \mathrm{P}_{2} \mathrm{O}_{5}\right)$ during soil preparation. Other cultural practices were carried out as recommended.

Harvesting and sampling

On the day before harvesting, 5 plants of each plot were taken with the soil surrounding roots as plant and soil samples. The plants were get rid of surrounding soil layer, washed, divided into roots and shoots and weighed. An additional sample of shoots was taken for oven drying. Fodder beet was harvested on the $20^{\text {th }}$ and $12^{\text {th }}$ of May for the first and the second season, respectively. At harvesting (190 days from sowing date), ten plants were randomly taken from each plot and the growth characteristics; root length $(\mathrm{cm})$, root diameter $(\mathrm{cm})$ and weight of top $\left(\mathrm{Mg} \mathrm{fad}^{-1}\right)$ were recorded (Illustrate 1.). The yield of each plot was recorded after obtaining all the plot plants which were roughly cleaned and weighed. Fresh yields of roots and tops were determined and samples were oven dried at $70^{\circ} \mathrm{C}$ to a constant weight as dry matter content.

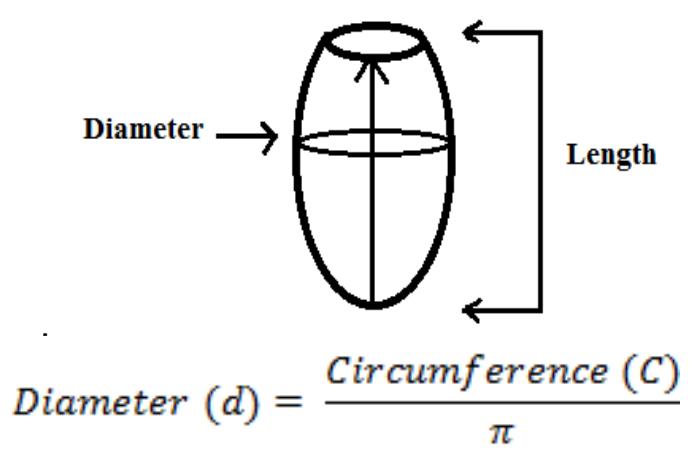

Illustrate 1. Root dimensions 


\section{Chemical analysis}

Root tissues were wet digested by a mixture of $\mathrm{HClO}_{4}$ and $\mathrm{H}_{2} \mathrm{SO}_{4}$ acids and their nutritional content was estimated as follows: $\mathrm{N}$ by semi micro Kjeldahl, $\mathrm{P}$ spectrophotometrically using stannous chloride reagent, $\mathrm{K}$ by the Flame photometer (Chapman and Pratt, 1961). Photosynthetic pigment (Chlorophyll a, b) in the fresh leaves and Proline content were estimated as described by Witham et al. (1971) and Bates et al., (1973), respectively. Protein percentage of root and top were calculated by multiplying the $\mathrm{N} \%$ by 6.25 (Hymowitz et al., 1972).

\section{Statistical analysis}

The experimental design was completely randomized blocks with three replicates. The obtained data were statistically analyzed using the Costat program and L.S.D. test at the probability levels of 5\% (Gomez and Gomez, 1984). The discussed data is the mean value for both seasons. The increase or decrease percent (\%) was calculated by dividing the difference between the specified treatment value and the control by the control.

\section{RESULTS}

\section{Effect of PEG and HA treatments on soil}

Data in Table (3) showed the effect of soaking seed in PEG or HA on some soil properties. Soil $\mathrm{pH}$ was almost unchanged. The EC values were decreased by $35.5 \%$ and $37.99 \%$ for both PEG and HA treatments respectively as the soaking time increased compared with the control. Similarly, soil available NPK for both seasons were increased. Maximum increase values were obtained for maximum soaking time (12 h). For PEG and $\mathrm{HA}$ respectively, available $\mathrm{N}$ was increased by $28.44 \%$ and $33.65 \%$; $\mathrm{P}$ was increased by $11.28 \%$ and $96.24 \%$ while $\mathrm{K}$ was increased by $13.14 \%$ and $18.5 \%$. The increases due to HA treatment were greater than that due to PEG.

Table 3: Some of the soil available nutrients as affected by different rates treatments

\begin{tabular}{|c|c|c|c|c|c|c|c|c|c|c|c|}
\hline \multirow[t]{2}{*}{ Treatments } & \multirow{2}{*}{$\begin{array}{l}\text { Soaking } \\
\text { time (h) }\end{array}$} & \multicolumn{2}{|c|}{$\begin{array}{c}\mathrm{pH} \\
(1: 2.5)\end{array}$} & \multicolumn{2}{|c|}{$\begin{array}{c}E C \\
\left(\mathrm{dS} \mathrm{m}^{-1}\right)\end{array}$} & \multicolumn{2}{|c|}{$\begin{array}{c}\mathbf{N} \\
(\mathbf{m g ~ k g})\end{array}$} & \multicolumn{2}{|c|}{$\begin{array}{c}P \\
(\mathrm{mg} \mathrm{kg})\end{array}$} & \multicolumn{2}{|c|}{$\begin{array}{c}\mathrm{K} \\
(\mathrm{mg} \mathrm{kg})\end{array}$} \\
\hline & & $1^{\text {st }}$ & $2^{\text {nd }}$ & $1^{\text {st }}$ & $2^{\text {nd }}$ & $1^{\text {st }}$ & $2^{\text {nd }}$ & $1^{\text {st }}$ & $2^{\text {nd }}$ & $1^{\text {st }}$ & $2^{\text {nd }}$ \\
\hline \multicolumn{2}{|c|}{ Control } & 8.06 & 8.03 & 8.37 & 7.66 & 38.25 & 40.89 & 3.97 & 4.01 & 185 & 188 \\
\hline \multirow{4}{*}{ PEG } & 6 & 8.04 & 8.01 & 6.10 & 5.81 & 43.85 & 43.98 & 4.25 & 4.32 & 200 & 208 \\
\hline & 8 & 8.03 & 8.00 & 5.99 & 5.14 & 49.25 & 51.20 & 4.39 & 4.45 & 203 & 212 \\
\hline & 12 & 8.01 & 7.98 & 5.38 & 4.96 & 50.76 & 50.99 & 4.42 & 4.46 & 208 & 214 \\
\hline & L.S.D. & \multicolumn{2}{|c|}{ ns } & \multicolumn{2}{|c|}{1.29} & \multicolumn{2}{|c|}{2.56} & \multicolumn{2}{|c|}{0.13} & \multicolumn{2}{|c|}{17.48} \\
\hline \multirow{4}{*}{$\mathrm{HA}$} & 6 & 8.02 & 7.97 & 7.96 & 6.57 & 47.21 & 48.29 & 4.69 & 4.73 & 213 & 218 \\
\hline & 8 & 8.01 & 7.95 & 5.57 & 5.04 & 52.19 & 53.06 & 4.72 & 7.78 & 218 & 220 \\
\hline & 12 & 7.98 & 7.95 & 5.14 & 4.80 & 52.63 & 53.14 & 7.81 & 7.85 & 219 & 223 \\
\hline & L.S.D. & \multicolumn{2}{|c|}{ ns } & \multicolumn{2}{|c|}{1.98} & \multicolumn{2}{|c|}{1.92} & \multicolumn{2}{|c|}{3.98} & \multicolumn{2}{|c|}{8.72} \\
\hline
\end{tabular}

Effect of PEG and HA treatments on fodder beet growth characteristics

According to the growth characteristics data presented in Table (4), it can be said that the fodder beet growth have been enhanced by soaking the seeds in PEG and/or HA solutions. The soaking time $12 \mathrm{~h}$ gave the highest 
enhancement. Humic acid seemed to be more effective than PEG in enhancing the studied fodder beet growth characteristics. In respect to soaking time the increases in the weight of fresh root, weight of dry root, root length, root diameter and weight of top amounted 133.3, 136.86, 22.67, 66.16 and $75.48 \%$ respectively, for the PEG treatment. For the HA treatments, the increases in the above mentioned characteristics amounted 155.26, 161.63, $31.05,70.69$ and $86.97 \%$, respectively.

Table 4: Fodder beet growth characteristics as affected by as affected by different rates of treatments

\begin{tabular}{|c|c|c|c|c|c|c|c|c|c|c|}
\hline \multirow[t]{2}{*}{ Treatments } & \multirow[t]{2}{*}{$\begin{array}{l}\text { Soaking } \\
\text { time (h) }\end{array}$} & \multicolumn{2}{|c|}{$\begin{array}{c}\text { Fresh weight } \\
\text { of root } \\
\left(\mathrm{Mg} \mathrm{fed}^{-1}\right)^{\star}\end{array}$} & \multicolumn{2}{|c|}{$\begin{array}{l}\text { Weight of } \\
\text { dry root }(\mathrm{Mg} \\
\left.\text { fed }^{-1}\right)\end{array}$} & \multicolumn{2}{|c|}{$\begin{array}{l}\text { Root } \\
\text { Length } \\
\text { (cm) }\end{array}$} & \multicolumn{2}{|c|}{$\begin{array}{c}\text { Root } \\
\text { Diameter } \\
(\mathbf{c m})\end{array}$} & $\begin{array}{l}\text { Weight of } \\
\text { Top } \\
\left(\mathrm{Mg} \mathrm{fed}^{-1}\right)\end{array}$ \\
\hline & & $1^{\text {st }}$ & $2^{\text {nd }}$ & $1^{\text {st }}$ & $2^{\text {nd }}$ & $1^{\text {st }}$ & $2^{\text {nd }}$ & $1^{\text {st }}$ & $2^{\text {nd }}$ & $1^{\text {st }} \quad 2^{\text {nd }}$ \\
\hline \multicolumn{2}{|c|}{ Control } & 10.59 & 11.27 & 1.59 & 1.72 & 34.39 & 34.41 & 8.12 & 8.46 & 12.6 \\
\hline \multirow{4}{*}{ PEG } & 6 & 18.94 & 22.70 & 2.59 & 2.70 & 38.14 & 38.55 & 12.80 & 12.85 & 21.4 \\
\hline & 8 & 22.39 & 25.63 & 3.25 & 3.60 & 42.10 & 42.16 & 13.64 & 13.74 & 22.2 \\
\hline & 12 & 24.83 & 26.17 & 3.55 & 4.29 & 42.19 & 42.21 & 13.73 & 13.82 & $22.7 \quad 23.1$ \\
\hline & L.S.D. & \multicolumn{2}{|c|}{6.68} & \multicolumn{2}{|c|}{1.07} & \multicolumn{2}{|c|}{0.54} & \multicolumn{2}{|c|}{0.19} & 1.39 \\
\hline \multirow{4}{*}{$\mathrm{HA}$} & 6 & 23.86 & 24.66 & 3.45 & 3.61 & 38.65 & 40.09 & 13.66 & 13.88 & $22.9 \quad 23.5$ \\
\hline & 8 & 25.59 & 27.29 & 3.75 & 3.88 & 44.97 & 45.00 & 14.05 & 14.10 & 23.4 \\
\hline & 12 & 27.66 & 28.14 & 3.77 & 4.89 & 45.04 & 45.12 & 14.12 & 14.18 & 24.1 \\
\hline & L.S.D. & \multicolumn{2}{|c|}{2.52} & \multicolumn{2}{|c|}{1.48} & \multicolumn{2}{|c|}{1.87} & \multicolumn{2}{|c|}{0.31} & 1.35 \\
\hline
\end{tabular}

Fodder beet roots and top macro-nutrient and protein contents as affected by different treatments

Tables (5a\&b) present the macro-nutrient and protein content of the fodder beet roots and tops at different treatments. As shown, the total NPK and protein \% were increased with increasing soaking time up to $12 \mathrm{~h}$ for both PEG and HA. The average increase percent (\%) in both seasons as follows:

(a) Roots; N: 22.6, $30.2 \%$ - P: 37.88, 50\% - K: 7.82, 12.35\% - Protein: $21.71,26.63 \%$ for $P E G$ and $H A$, respectively, at $12 \mathrm{~h}$ soaking time.

b) Tops; N: 5.88, 17.23 \% - P: 29.31, 43.1\% - K: 6.78, 8.81\% - Protein:

$5.82,16.63 \%$ for $\mathrm{PEG}$ and $\mathrm{HA}$, respectively, at $12 \mathrm{~h}$ soaking time.

Table 5(a): Fodder beet roots and top roots macro-nutrient and protein content as affected by different rates of treatments (a) Roots.

\begin{tabular}{|c|c|c|c|c|c|c|c|c|c|}
\hline \multirow{2}{*}{ Treatments } & \multirow{2}{*}{$\begin{array}{l}\text { Soaking } \\
\text { time (h) }\end{array}$} & \multicolumn{2}{|c|}{$\mathbf{N}(\%)$} & \multicolumn{2}{|c|}{$\mathbf{P}(\%)$} & \multicolumn{2}{|c|}{$\mathrm{K}(\%)$} & \multicolumn{2}{|c|}{ Protein (\%) } \\
\hline & & $1^{\text {st }}$ & $2^{\text {na }}$ & $1^{\text {st }}$ & $2^{\text {na }}$ & $1^{\text {st }}$ & $2^{\text {na }}$ & $1^{\text {st }}$ & $2^{\text {na }}$ \\
\hline \multicolumn{2}{|c|}{ Control } & 1.59 & 1.63 & 0.31 & 0.35 & 2.41 & 2.45 & 9.94 & 10.19 \\
\hline \multirow{4}{*}{ PEG } & 6 & 1.84 & 1.88 & 0.38 & 0.41 & 2.54 & 2.56 & 11.5 & 11.75 \\
\hline & 8 & 1.93 & 1.94 & 0.41 & 0.43 & 2.58 & 2.60 & 12.06 & 12.13 \\
\hline & 12 & 1.95 & 1.97 & 0.45 & 0.46 & 2.61 & 2.63 & 12.19 & 12.31 \\
\hline & L.S.D. & \multicolumn{2}{|c|}{0.06} & \multicolumn{2}{|c|}{0.05} & \multicolumn{2}{|c|}{0.05} & \multicolumn{2}{|c|}{0.37} \\
\hline \multirow{4}{*}{$\mathrm{HA}$} & 6 & 1.95 & 1.98 & 0.37 & 0.39 & 2.64 & 2.66 & 12.18 & 12.37 \\
\hline & 8 & 2.03 & 2.06 & 0.44 & 0.47 & 2.68 & 2.71 & 12.69 & 12.87 \\
\hline & 12 & 2.07 & 2.10 & 0.48 & 0.51 & 2.72 & 2.74 & 12.37 & 13.12 \\
\hline & L.S.D. & \multicolumn{2}{|c|}{0.07} & \multicolumn{2}{|c|}{0.06} & \multicolumn{2}{|c|}{0.05} & \multicolumn{2}{|c|}{1.03} \\
\hline
\end{tabular}


Table 5(b): Top

\begin{tabular}{|c|c|c|c|c|c|c|c|c|c|}
\hline \multirow{2}{*}{ Treatments } & \multirow{2}{*}{$\begin{array}{l}\text { Soaking } \\
\text { time (h) }\end{array}$} & \multicolumn{2}{|c|}{ N (\%) } & \multicolumn{2}{|c|}{$\mathbf{P}(\%)$} & \multicolumn{2}{|c|}{ K (\%) } & \multicolumn{2}{|c|}{ Protein (\%) } \\
\hline & & $1^{\mathrm{st}}$ & $2^{\text {nd }}$ & $1^{\mathrm{st}}$ & $2^{\text {nd }}$ & $1^{\mathrm{st}}$ & $2^{\text {nd }}$ & $1^{\text {st }}$ & $2^{\text {nd }}$ \\
\hline \multicolumn{2}{|c|}{ Control } & 2.38 & 2.43 & 0.28 & 0.30 & 2.92 & 2.98 & 14.87 & 15.19 \\
\hline \multirow{4}{*}{ PEG } & 6 & 2.45 & 2.49 & 0.33 & 0.34 & 3.05 & 3.09 & 15.31 & 15.56 \\
\hline & 8 & 2.49 & 2.53 & 0.35 & 0.37 & 3.09 & 3.12 & 15.56 & 15.81 \\
\hline & 12 & 2.52 & 2.57 & 0.37 & 0.38 & 3.12 & 3.18 & 15.75 & 16.06 \\
\hline & L.S.D. & \multicolumn{2}{|c|}{0.1} & \multicolumn{2}{|c|}{0.03} & \multicolumn{2}{|c|}{0.1} & \multicolumn{2}{|c|}{0.61} \\
\hline \multirow{4}{*}{$\mathrm{HA}$} & 6 & 2.63 & 2.66 & 0.32 & 0.35 & 3.10 & 3.14 & 16.44 & 16.62 \\
\hline & 8 & 2.75 & 2.77 & 0.37 & 0.38 & 3.15 & 3.18 & 17.18 & 17.31 \\
\hline & 12 & 2.79 & 2.82 & 0.41 & 0.42 & 3.20 & 3.22 & 17.44 & 17.62 \\
\hline & L.S.D. & \multicolumn{2}{|c|}{0.06} & \multicolumn{2}{|c|}{0.04} & \multicolumn{2}{|c|}{0.07} & \multicolumn{2}{|c|}{0.37} \\
\hline
\end{tabular}

Fodder beet leaves characteristics as affected by different treatments

At different treatments of PEG and HA, the content of Chl, proline and percent of emergence of leaves varied significantly (Table 6). As the soaking time increased the $\mathrm{Chl}$ content and emergence percent increased while the proline content decreased. At soaking time $12 \mathrm{~h}$, the $\mathrm{Ch} /$ content increased by $84.43 \%$ and $156.51 \%$ and emergence by $36.36 \%$ and $42.15 \%$ while the proline decreased by $16.07 \%$ and $25.71 \%$ for PEG and HA, respectively.

Table (6): Fodder beet leaves characteristics as affected by different rates of treatments

\begin{tabular}{|c|c|c|c|c|c|c|c|}
\hline \multirow[t]{2}{*}{ Treatments } & \multirow[t]{2}{*}{$\begin{array}{l}\text { Soaking } \\
\text { time } \\
\text { (h) }\end{array}$} & \multicolumn{2}{|c|}{$\begin{array}{c}\text { Chlorophyll } \\
(a+b) \\
\text { (mg/g. f.w.) }\end{array}$} & \multicolumn{2}{|c|}{$\begin{array}{c}\text { Proline } \\
(\mu \mathrm{mol} / \mathrm{g} . \text { leaf } \\
\text { tissue.) }\end{array}$} & \multicolumn{2}{|c|}{$\begin{array}{c}\text { Plant } \\
\text { Emergence } \\
(\%)\end{array}$} \\
\hline & & $1^{\mathrm{st}}$ & $2^{\text {nd }}$ & $1^{\mathrm{st}}$ & $2^{\text {nd }}$ & $1^{\text {st }}$ & $2^{\text {nd }}$ \\
\hline \multicolumn{2}{|c|}{ Control } & 2.95 & 2.96 & 0.141 & 0.139 & 59 & 62 \\
\hline \multirow{4}{*}{ PEG } & 6 & 4.19 & 4.22 & 0.128 & 0.122 & 66 & 69 \\
\hline & 8 & 5.37 & 5.39 & 0.121 & 0.117 & 75 & 78 \\
\hline & 12 & 5.44 & 5.46 & 0.120 & 0.115 & 81 & 84 \\
\hline & L.S.D. & \multicolumn{2}{|c|}{0.05} & \multicolumn{2}{|c|}{0.01} & \multicolumn{2}{|c|}{6.75} \\
\hline \multirow{4}{*}{$\mathrm{HA}$} & 6 & 6.82 & 6.88 & 0.119 & 0.114 & 71 & 74 \\
\hline & 8 & 7.10 & 7.14 & 0.112 & 0.109 & 79 & 82 \\
\hline & 12 & 7.56 & 7.60 & 0.105 & 0.103 & 85 & 87 \\
\hline & L.S.D. & \multicolumn{2}{|c|}{0.11} & \multicolumn{2}{|c|}{0.01} & \multicolumn{2}{|c|}{6.09} \\
\hline
\end{tabular}

\section{DISCUSSION}

Results of the present study indicated that the concentration of the macro-nutrients $\mathrm{N}, \mathrm{P}$ and $\mathrm{K}$ in the available and total states is positively affected by soaking the fodder beet seeds in the PEG and HA solutions compared to the un-soaked seeds under salinity conditions. These results were in agreement with the results mentioned by Provenza et al., 2000. Additionally, the roots protein and leaves $\mathrm{Chl}$ content increased while the proline accumulation decreased. The fresh and dry weight of root as well as the root length and diameter were enhanced significantly. The soaking time appeared to have a great effect on the product characteristics as indicated 
previously (Yasari et al., 2013). A twelfth hour soaking time gave the highest values for the estimated parameters for the current study. The solutions of PEG and HA might have been affected the fodder beet seeds chemically and physiologically through creating a specific osmotic pressure atmosphere surrounding the seeds leading to a promoted growth indices (Jain et al., 2013). Humic acid treatments showed promising effects as stated earlier due to its bio-compatibility being the principle organic matter (Paksoy et al., 2010; Eisa et al., 2012; Jain et al., 2013).

In the present study, the effect of PEG and HA is expected to be reflected at the root distribution zone (RDZ) being the zone of contact with soil. Their chemical structure will often play an important control role within the soil matrix affecting the mobility and concentration of the soluble ions in the soil solution rather than the acid-base balance. At basic medium (soil pH $8.03-8.06>7$ ), protons $\mathrm{H}^{+}$are less competing for the partially dissociated hydroxyl $(-\mathrm{OH})$ functional groups of PEG and $\mathrm{HA}$ than other soluble cations. Another concept may be suggested, that is a thin layer of polymers coats seeds and/or soil particles forming a semi-permeable membrane which restricts soluble ions distribution and hence the osmotic pressure within the RDZ. Partitioning of labile species including soluble salts and nutrients may be highly controlled by the osmotic pressure created by the macromolecules, PEG and HA. Specific solute-membrane interactions may occur and in turn, the absorption of nutrients by the plant roots will be affected.

Photosynthetic pigments determine the physiological status of the plants. Chlorophyll is the molecule that acts as a photoreceptor. Entire pathway of $\mathrm{Chl}$ biosynthesis is operated in plastids by a complex set of reactions involving many intermediates. The change in the $\mathrm{Chl}$ provides further information about the process taking place in the photosynthetic apparatus. Increase in $\mathrm{Chl}$ content has been demonstrated in graminaceous chlorophyllic cell lines of grass Bouteloua gracilis exposed to different concentrations of PEG 8000 (PEG 6000 imposed water deficit has affected the activities of enzymes of $\mathrm{Ch}$ metabolism also). Salinity has been found to enhance the chlorophyllase activity in pigeonpea and Gingellay which results in lowering of chlorophyll content (Jain et al., 2013).

Proline accumulation under stress has been linked with its role as an osmolyte by contributing towards osmotic adjustment between cytoplasm and vacuoles. Because of its zwitter ionic and highly hydrophilic character it has a role as an osmoticum and acts as a compatible solute for plants subjected to low water potential and other environmental stresses. Increase in the free proline content during water stress condition due to PEG has been stated (Jain et al., 2013).

Finally, it could be concluded that presented soaking seeds of fodder beet to different time 8 and $12 \mathrm{~h}$ were effect on the productivity and quality of fodder beet crops under saline soil conditions. 


\section{REFERENCES}

Ajirloo, A.R.; M.S. Ghorban; D. Moghanloo and A. Ahmadi ( 2013). Effect of priming on seed germination characteristics of wheat (Triticum aestivum L.). Int. J. Agr. Crop Sci. 5(15), 1670-1674.

Bates, L.S.; R.P. Waldren and I.D.Teare (1973). Rapid determination of free proline under water stress studies. Plant and Soil. 39, 205-207.

Ben Hassine, A. and S. Lutts ( 2010). Differential responses of saltbush Atriplex halimus $\mathrm{L}$. exposed to salinity and water stress in relation to senescing hormones abscisic acid and ethylene. J. Plant Phys. 167, 1448-1456.

Chakwizira, E.; E.D. Meenken; S. Maley; M. George; R. Hubber ; J. Morton and A. A. Stafford (2013). Effects of potassium, sodium and chloride fertiliser rates on fodder beet yield and quality in Canterbury. Proc. New Zea. Grassland Associat. 75, 261-270.

Chapman, H.D and P.F.Pratt (1961). Methods of Analysis for Soils (Plants and Waters), The University of California's Division of Agriculture Sciences, Davis, Calif, USA.

Eisa, S.S., A.M. Ibrahim; H.S. Khafga and S.A. Shehata (2012). Alleviation of adverse effect of salt stress on sugar beet by pre- sowing seed treatments. J. Appl. Sci. Res. 8 (2), 799-806.

Fahim, M.G.; B. Mirzamasoumzadeh, and B. Ahadzadeh, , 2014. Effect of polyethylene glycol on the amount of chlorophyll $a$, chlorophyll $b$ and total leaf of sugar beet genotypes. J. Bio. Env. Sci., 4(1): 233-237.

Gomez, K.A. and A.A. Gomez ( 1984). Statistical Procedures for Agricultural Research, John Wiley \& Sons, New York, NY, USA.

Hymowitz, T.F.; P. Collins and W.M Walker (1972). Relationship between the content of oil, protein and sugar in soybean seed. Agron. J., 64: 613616.

lqbal, N.; A. Trivellini; A. Masood; A. Ferrante and N.A. Khan (2013). Current understanding on ethylene signaling in plants: The influence of nutrient availability: review. Plant Phys. Biochem. 73, 128-138.

Ivetić, D.Ž.; M.B. Šćiban and M.G. Antov (2012). Enzymatic hydrolysis of pretreated sugar beet shreds: Statistical modelling of the experimental results. Biomass. Bio Ener. 47, 387-394.

Jackson, M.L., (1973). Soil Chemical Analysis, Prentice-Hall, Inc., Englewood Califfs, New Jersy.

Jain, M.; M. Mittal and R. Gadre (2013). Effect of PEG-6000 Imposed Water Deficit on Chlorophyll Metabolism in Maize Leaves. J. Stress Phys. Biochem. 9(3), 262-271.

Mardani, Z.; B. Rabiei; H. Sabouri and A. Sabour(2013). Mapping of QTLs for Germination Characteristics under Non-stress and Drought Stress in Rice. Rice Sci. 20(6), 391-399.

Nagl, N.; I. Maksimovic; Z. Curcic; M. Putnik-Delic and L. Kovacev (2010). Effect of induced water deficit on sugar beet micro-propagation. Proceedings of Papers, $72^{\text {nd }}$. IIRB Congress - 22-24/06/2010 Copenhagen. 
Olsen, S.R. and L.E., Sommers (1982). Phosphorus. In: Page AL, Miller RH (Eds). Methods of Soil Analysis," Part 2. $2^{\text {nd }}$ ed. Agron Monog 9, ASA and SSSA, Madison, WI, pp: 403-430.

Paksoy, M.; Ö. Türkmen and A. Dursun (2010). Effects of potassium and humic acid on emergence, growth and nutrient contents of okra (Abelmoschus esculentus L.) seedling under saline soil conditions. Afr. J. Biotechnol. 9(33), 5343-5346.

Piper, C.S., (1950). Soil and plant analysis, Inter. Sci . Publishers. Inc., New York.

Provenza, F.D.; E.A. Burritt; A. Perevolotsky and N. Silanikove (2000). Selfregulation of intake of polyethylene glycol by sheep fed diets varying in tannin concentrations. J. Anim. Sci. 78, 1206-1212.

Rozema, J. (1995). Biology of halophytes. In: Choukr-Allah, R.,Malcom, C. V. and Hamdy, A. (eds.). Halophytes in biosaline agriculture. Marcel Dekker, Inc. pp. 17-30.

Sidari, M.; C. Mallamaci; A. Muscolo and A. Drought (2008). Salinity and heat differently affect seed germination of Pinus pinea. J. For. Res. 13, 326-330.

Silva, P.O.; E.F. E.F. Medina; R.S. Barros and D.M. Ribeiro, (2014). Germination of salt-stressed seeds as related to the ethylene biosynthesis ability in three Stylosanthes species. J. Plant Phys. 171, 14-22.

Valdrighi, M.M.; A. Pear; M. Agnolucci; S. Frassinetti; D. Lunardi and G. Vallini (1996). Effects of compost derived humic acid on vegetable biomass production and microbial growth within a plant (Cichorium intybus) soil system: a comparative study. Agri. Ecosys. Environ. 58, 133-144.

Witham, F.H.; D.F. Blaydes and P.M.Devin (1971). Experiments in plant physiology. Van Nosland Reihold. Co. New York, 55-58.

Wu, C.; Q. Wang; B. Xie; Z. Wang; J. Cui and T., Hu (2011). Effects of drought and salt stress on seed germination of three leguminous species. Afr. J. Biotechnol. 10(78), 17954-17961.

Yang, X-Y.; J-X. Xie; X.P. Lu; Y.Z. Liu and S.A. Peng (2011). Isolation of a citrus ethylene-responsive element binding factor gene and its expression in response to abiotic stress, girdling and shading. Sci. Hort. 127, 275-281.

Yasari, E.; K.O. Saravi and S.Y. Soraki (2013). Evaluation of the Responses of the Seeds of the Single - Cross 499 Cultivar of Corn (Zea mays L.) to Various Priming Combinations. Int. J. Agri. Crop Sci. 5(6), 585-590. 
تأثير نقع البذور فى محاليل البولى إيثيلين جليكول وحمض الهيوميك على إنتاجية

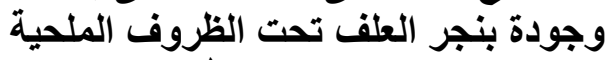

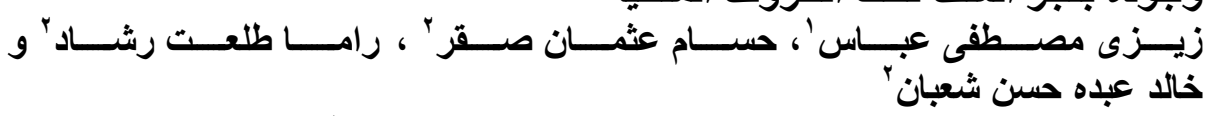

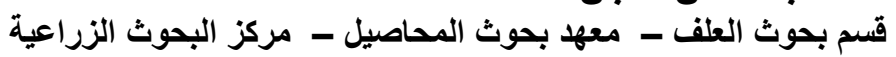

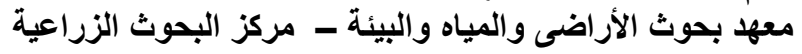

أجريت تجربتان حقليتان فى موسمى شتاء 2012/2011 و 2013/2012 في محطة البحوث

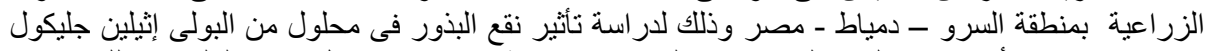

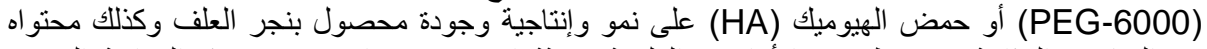

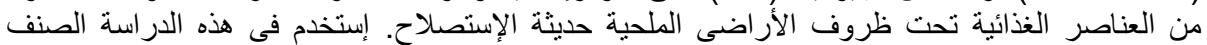
وهو من أصناف بنجر العلف متعددة الأجنة.

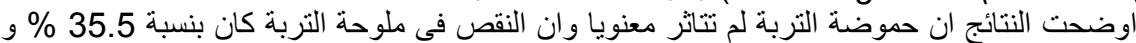
37.99 \% بينما زادت محتوى التربة من العناصر النتروجين و الفوسفور و والبوتناسيوم بنسبة 28.55 و 28.44 و و و

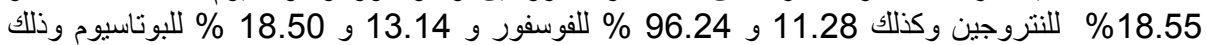

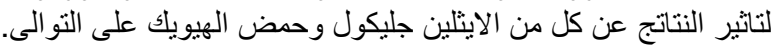

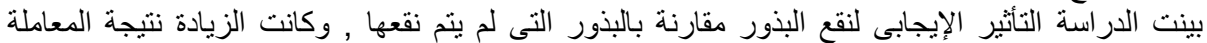

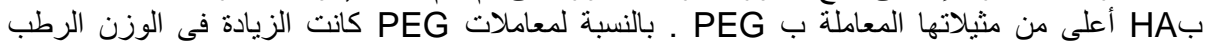

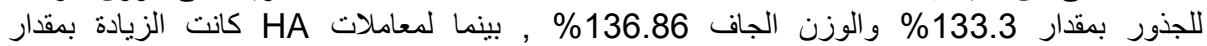

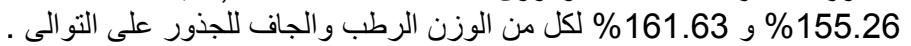

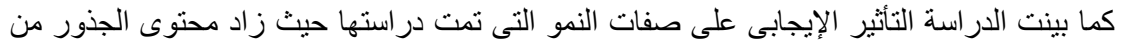

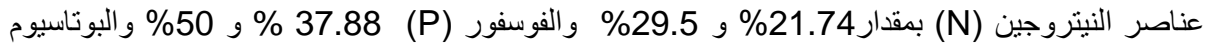

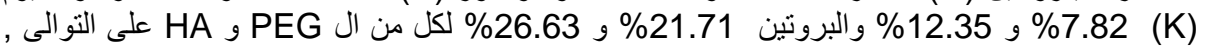

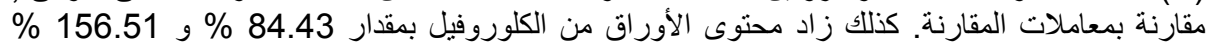

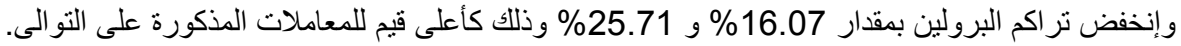

